\title{
Impact of Export Activities on Firm Performance: The Case of Indonesian SMEs
}

\author{
Mohamad D. Revindo \\ Institute for Economic and Social Research, Faculty of \\ Economic and Business \\ University of Indonesia \\ Jakarta, Indonesia \\ revindo@lpem-feui.org
}

\author{
Devianto \\ Institute for Economic and Social Research, Faculty of \\ Economic and Business \\ University of Indonesia \\ Jakarta, Indonesia \\ devianto@lpem-feui.org
}

\begin{abstract}
Firms venture abroad with a view to gaining many benefits, including revenue growth, above-normal returns, less revenue uncertainty, realization of economies of scale and scope, lower average cost of input, higher efficiency and enhanced competitiveness in domestic markets. This study investigates the impact of exporting on firm performance, with reference to Indonesian small and medium-sized enterprises (SMEs). The study uses primary data from the survey on 271 exporting SMEs in seven provinces in Jawa-Bali Region. The results show that SMEs experienced greatest performance improvement in product quality and least improvement in domestic sales after exporting. The results also showed that firm performance exhibits an inverted $U$-shaped relationship with export intensity. The policy and academic implications of the findings are discussed.
\end{abstract}

Keywords- export activities, SMEs, export impact, Indonesia, export performance

\section{INTRODUCTION}

Small and medium-sized enterprises (SMEs) have been Indonesia's major source of business establishments, employment opportunities and value-added creation [1][2]. However, SMEs only accounted for a small share of Indonesia's non-oil and gas exports and their share tend to decline over time, from around $18.5 \%$ in $2005-07$ to $16.9 \%$ in $2008-10$ and further down to $15.4 \%$ between 2011 and 2013.

Previous studies have extensively documented the preexport activities of Indonesian SMEs, but only a few shed lights on their post-export market entry activities, with the exception of Wengel \& Rodriguez [3], Revindo \& Gan [4][5] and Revindo [6]. This study focuses on post-export behavior, particularly it aims to analyze the impact of export activities on the performance of Indonesian SMEs.

\section{LITERATURE REVIEW}

Firms venture abroad with a view to gaining many benefits. International markets offer almost unlimited market expansion opportunities for the firms and thereby their growth [7]. Cross-border business activities allow the firms to gain above-normal returns if they can exploit foreign market imperfections and niche markets using their firm-specific and intangible assets [7][8]. Market diversification may reduce the firms' revenue uncertainty through the spreading risk of market slump in different countries [9]. Market expansion enables the firms to realize economies of scale and scope through larger production levels and product diversification [7][10]. Larger production levels may lower the average cost of input through bulk purchasing [11]. International business activities may also positively affect the firms' efficiency through organizational and experiential learning, including an enhanced knowledge base, capabilities, innovations and competitiveness [8]. Enhanced competitiveness from international operations may in turn also reinforce the firms' revenue in domestic markets [8].

However, internationalization also implies some significant costs for firms. The cross-border business activities incur some costs typically associated with the firms' newness and foreignness (i.e. unfamiliarity with local cultural, political and economic environments) [8][12]. Foreign market operation is also complex and laborious to manage. Transaction, coordination, distribution and logistical costs are among the types of costs that may arise from managing overseas business activities [7][12].

Owing to the complexity and the enormous barriers and costs associated with foreign market expansion, the relationship between internationalization and firms' performance is less straightforward than the expected multiple benefits of internationalization. Some studies reported that internationalization has positive and linear relationships with performance [13][14][15]. Some studies reported that internationalization has a non-linear relationship with performance. For example, firms' performance may accelerate or decelerate with market diversification [15]; exhibit a U-form relationship, with performance being high at low degrees of internationalization, low at medium degrees of internationalization and pick up again at high degrees of internationalization [16]; exhibit inverted U-shaped relationship [7]; and even take a horizontal sigmoid Sshaped relationship [8]. Other studies reported that the relationship between internationalization and performance is non-existent or weak at best [17][18] and some other studies even reported that internationalization may have negative effects on firms' performance [17][19][20].

Hence, the previous empirical studies on internationalization and performance have yielded mixed 
results. Variation of results is evident across countries, industries, time periods of the studies, internationalization forms, performance measures and firm size. A study focusing on the impact of export activities on the performance of SMEs in a developing country (Indonesia as a case) is therefore highly appropriate to further enrich the extant literature.

\section{DATA AND METHOD}

\section{A. Data}

This study refers to the definition of SMEs by number of employees (5 to 99) used by BPS-Statistic Indonesia. The primary data was collected through a survey using a structured questionnaire. The target population of this study is the SMEs that operate in seven provinces in Jawa, Madura and Bali islands where approximately $60 \%$ of the SMEs in the country are concentrated [21][22].

In order to construct the sample frame, we merged four different databases into one list of SMEs from which the samples were picked. The first three databases were published by the Ministry of Cooperatives and SMEs including: (1) the Ministry of Cooperatives and SMEs' online trading board (http://www.indonesian-products.biz); (2) SME and Cooperative Indonesia Catalogue [23][24]; and (3) Exporting SMEs Directory book, listing all SMEs that participated in international trade shows during 20052009 [25]. The fourth database is the Indonesian 2006 Economic Census provided by BPS-Statistics Indonesia.

The survey was administered in April - August 2014, with usable responses consisted of 271 exporting SMEs. The distribution of the sample by province is as follows: Banten (4.1\%), DKI Jakarta (20.7\%), Jawa Barat (7.0\%), Jawa
Tengah (4.8\%), DI Yogyakarta (19.6\%), Jawa Timur $(28.0 \%)$ and Bali $(15.9 \%)$. The distribution of surveyed SMEs by their commodities is as follows: Agricultural Products $(8.5 \%)$, Food \& Beverages $(6.3 \%)$, Furniture (15.9\%), Handicrafts $(21.8 \%)$, Garments (12.2\%), Leather Products \& Fashion Accessories (5.5\%), Household Utensils (5.5\%), Machinery Components (2.6\%), Other Products (3.3\%) and Multiple Products (18.5\%).

\section{B. Data Analysis}

In the survey, the exporting SME respondents were asked whether they perceived an improvement in firm performance since they began exporting. Eight indicators of firm performance were used in the questionnaire including total profit, total sales, domestic sales, labor productivity, product quality, production techniques and technology, cost efficiency, and marketing and networking. The respondents were asked to indicate the level of improvement in each firm performance indicator in a three-point Likert-scale (where 1 $=$ no improvement, $2=$ improved and $3=$ improved significantly).

We expect that the level of improvement of firm performance would vary across exporting SMEs. Hence, we estimate the determinants of firm performance improvement with regression analysis. Table I gives the description and the $a$ priori sign of each independent variable.

The export impact model is estimated with OLS and GLM regression techniques. OLS regression is applicable because the dependent variable (average Likert response score of eight indicators of firm performance) is a continuous number that can take any value between 1 (minimum average Likert score response) and 3 (maximum average Likert score response). However, Papke \& Wooldridge [26]

TABLE I. INDEPENDENT VARIABLES FOR EXPORT IMPACT ESTIMATION

\begin{tabular}{|c|c|c|}
\hline Variables & Description & Priori Sign \\
\hline \multicolumn{3}{|l|}{ Firm Characteristics } \\
\hline FirmSize & $\begin{array}{l}\text { Firm size by number of employees, where } 1=\text { medium-sized enterprise }(20-99 \text { employees }) \text { and } 0=\text { small- } \\
\text { sized enterprise }(5-19 \text { employees })\end{array}$ & + \\
\hline FirmAge & Number of years the firm has been operating by the time of the survey since the firm's establishment & + \\
\hline \multicolumn{3}{|c|}{ Owner's Characteristics } \\
\hline OwnerGender & Owner's gender, where $1=$ male, $0=$ female & $+/-$ \\
\hline OwnerEducHigh & $\begin{array}{l}\text { Owner's educational attainment, where } 1 \text { if the owner is a college graduate or higher and } 0 \text { if a high school } \\
\text { graduate or lower }\end{array}$ & + \\
\hline OwnerAge & Owner's age at the time of the survey & + \\
\hline \multicolumn{3}{|c|}{ SME's International Activities } \\
\hline Exportintensity & Share of export sales in total sales & + \\
\hline ExportIntensitySq & The squared term of ExporIntensity & $+/-$ \\
\hline YearsExporting & Number of years the SME had been exporting at the time of the survey & + \\
\hline ForeignInvestor & 1 if the SME is partially or fully owned by foreign investors, 0 otherwise & + \\
\hline \multicolumn{3}{|c|}{ Network Relationships and External Assistance } \\
\hline GovCentral_Assist & $\begin{array}{l}1 \text { if SME received either promotional, business management, finance or production assistance from any } \\
\text { central government agencies }\end{array}$ & + \\
\hline GovtLocal_Assist & $\begin{array}{l}1 \text { if SME received technical or managerial training, grants or promotional assistance from any local } \\
\text { (provincial, regency or municipal) government agencies }\end{array}$ & + \\
\hline NonGovt_Assist & $\begin{array}{l}1 \text { if SME received any type of assistance from either business association/chambers, universities/research } \\
\text { institutes, private companies/SOEs, business partners/associates, family/relatives or Indonesian emigrant } \\
\text { communities }\end{array}$ & + \\
\hline
\end{tabular}


proposed a Generalized Linear Model (GLM) estimation procedure to model outcomes with extreme values of the dependent variable. Hence, we first transform our target variable into the index of firm performance improvement that takes value between 0 and 1 , and then apply the fractional logit regression.

\section{RESULTS}

\section{A. Descriptive Statistics}

Table II shows that six performance indicators have average response scores above 2.0, including four operational performance indicators (product quality, marketing and networking techniques, production techniques/technology and worker productivity) and two financial performance indicators (total sales and total profit). The average response scores above 2.0 imply that SMEs have perceived improvement in the six performance indicators after they began exporting.

SMEs perceived the greatest performance improvement in product quality after exporting. Exporting SMEs should adapt to overseas customers and markets' demand that usually require higher product quality level and standards than domestic markets [27][28]. Exporting SMEs are also inclined to improve their product quality to minimize foreign buyers' complaints and product rejection.

However, two indicators of firm performances have average response scores below 2.0: domestic sales and efficiency. The average response scores below 2.0 imply that exporting activities neither boosted SMEs' domestic sales nor increased efficiency in terms of cost of production. The unit cost of production is difficult to be driven down possibly because SMEs must maintain a high quality of their exported products, which requires a high cost of raw materials and labor inputs. Moreover, exporting does not improve SMEs' domestic sales, possibly because SMEs exhaust most of the limited resources for export production at the expense of domestic market-oriented products.

\section{B. Estimation Results}

Table III gives the estimation results of the two regression models. There are high degrees of consistency/ similarity of OLS and GLM estimation results of export impact. However, we use the GLM regression results as the main reference for further analysis due to GLM's superiority over OLS in modelling bounded dependent variables [29][30].

Firm size has a positive and significant effect on SMEs' performance improvement. On average, medium-sized enterprises exhibit a $6.3 \%$ higher performance index than small-sized enterprises, holding other factors constant.

With respect to owners' characteristics, OwnerEducation has a positive and significant effect. On average, SMEs whose owners are college graduates or have higher education exhibit a $4.6 \%$ higher performance improvement index than SMEs owners who are high school graduates or lower.

SMEs' performance improvement after exporting is also influenced by the presence of foreign investors. SMEs whose share are partially or totally owned by foreign investors on average experience a $11.1 \%$ higher improvement index than SMEs with no foreign ownership. It is argued that the presence of foreign investors allow SMEs to absorb innovations and entrepreneurship skills and acquire specific resources and capabilities from their investors or parent companies, all of which positively affect the firm's performances and competitiveness [31].

The estimated coefficient of Years Exporting is negative and significant at the $10 \%$ level. The shorter period the SMEs have been exporting, the more positive performance improvement they perceive, and vice versa. On average, one year less in exporting accounts for a $0.4 \%$ higher performance improvement index, ceteris paribus. Many of the newly exporting SMEs are young firms that belong to "born global enterprises", characterized by strong international orientation since their establishment [32]. These young exporting SMEs are probably better prepared and equipped in capitalizing the benefit of export activities to

TABLE II. IMPROVEMENT IN SMEs' PERFORMANCES AFTER EXPORTING

\begin{tabular}{|c|c|c|c|c|c|}
\hline Firm Performance Indicators & $\begin{array}{l}\text { Means of } \\
\text { Responses }\end{array}$ & Likert-Scale & $\begin{array}{l}\text { Std. } \\
\text { Deviation }\end{array}$ & $\begin{array}{l}\text { Std. } \\
\text { Mean }\end{array}$ & Error \\
\hline Product quality & 2.30 & & .591 & .039 & \\
\hline Marketing and networking techniques & 2.15 & & .625 & .041 & \\
\hline Total sales & 2.11 & & .616 & .040 & \\
\hline Total profit & 2.09 & & .524 & .034 & \\
\hline Production technique/technology & 2.08 & & .666 & .044 & \\
\hline Worker productivity & 2.06 & & .601 & .039 & \\
\hline Efficiency (per unit cost of production) & 1.86 & & .592 & .039 & \\
\hline Domestic sales & 1.85 & & .687 & .045 & \\
\hline
\end{tabular}


TABLE III. OLS AND GLM ESTIMATES FOR EXPORT IMPACT

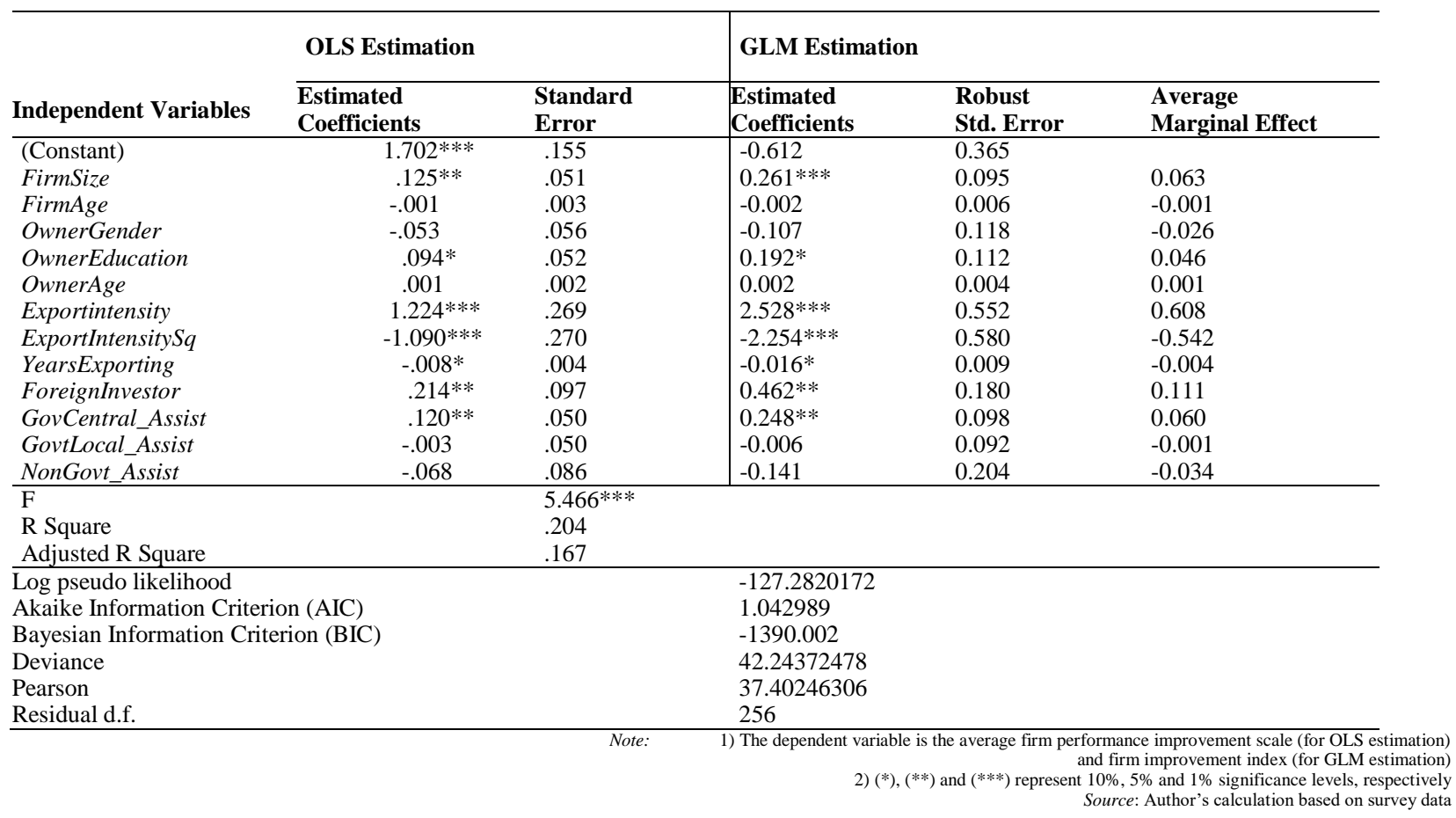

improve their overall performances. This may also explain the insignificance of the estimated coefficient of firm age. Moreover, the established exporters may have been constrained in expanding their exports and thereby perceive lower firm performance improvement.

Firm performance improvement is also affected by the export intensity. Interestingly, the estimated coefficient of export intensity is positive while its squared term is negative. Hence, the performance improvement exhibits an inverted U-shaped relationship with export intensity. SMEs at lower export intensity perceive little improvement in firm performance. As the export intensity increases slightly, SMEs perceive higher performance improvement. However, as the export intensity further increases, the perceived performance improvement eventually decreases.

The export assistance provision by the government agencies also influences the impact of exporting on SMEs performance. On average, exporting SMEs that have received any type of assistance from any central government agencies have a $6 \%$ performance improvement index higher than non-recipient SMEs. However, the GovtLocal_Assist (including assistance by provincial, municipal and regency government agencies) has no significant effect on the firm performance improvement. While local government may have a better understanding of the SMEs in their region, they may not have adequate resources to assist SMEs with export activities. It is also common for local government to deliberately direct local SMEs to compete in domestic markets [33]. Likewise, NonGovt Assist is not statistically significant as the non-governmental actors may have limited resources and capabilities to help SMEs utilize export activities to leverage their overall performances.

\section{CONCLUSIONS AND IMPLICATIONS}

The findings of this study have several policy implications. First, the policy makers should not focus solely on the effort to assist non-exporting SMEs to become exporters. Rather, it should closely assist and monitor SMEs' export sustainment and expansion beyond initial export success until they experience improvements in firm performance. Second, the government should enhance exporting SMEs' capability to increase their export sales and intensity. This is crucial as otherwise SMEs, due to their limited resources, will experience a decline in firm performance when the export intensity is increasing further. Third, the central government must disseminate this policy on provincial, municipal and regency governments. Our estimation results show that local government assistance has no significant effect in helping SMEs to sustain and expand their export.

The findings of this study also have a couple managerial implications for the current exporting SMEs. First, despite the impediments at the exporting stage, current exporters should always consider expanding their exports. Second, SMEs' owner and the managerial team should keep actively seeking to participate in various government export assistance programs.

Future research in this topic can be expanded to include other regions or provinces in Indonesia. Alternatively, future research can be more specific on SME internationalization in a particular province/region or product group/industry. Future research can also consider SME definitions that incorporate other dimensions of size including, for example, assets and turnover values. To improve the accuracy of the research data, some perceptual data can be replaced with factual (quantitative) data. Finally, the use of panel data or 
pool cross-sectional methods will significantly improve the estimation results of export impact in future studies.

\section{REFERENCES}

[1] Ministry of Cooperatives and SMEs Republic of Indonesia. (2009b) Perkembangan Data Usaha Mikro, Kecil, Menengah (UMKM) dan Usaha Besar (UB) Tahun 2005-2009.

[2] Ministry of Cooperatives and SMEs Republic of Indonesia. (2015b) Perkembangan Data Usaha Mikro, Kecil, Menengah (UMKM) dan Usaha Besar (UB) Tahun 2012-2013.

[3] Wengel, J. t., \& Rodriguez, E. (2006). SME export performance in Indonesia after the crisis. Small Business Economics, 26(1), 25-37. doi:10.1007/s11187-004-6491-y

[4] Revindo, M.D., \& Gan, C. (2016). Export Stimuli, Export Stages and Internationalization Pathways: The Case of Indonesian SMEs. Economics and Finance in Indonesia, 62(3), 191-205.

[5] Revindo, M. D., \& Gan, C. (2018). Factors Affecting Variation in SMEs' Export Intensity (LPEM Working Paper Series No. 201820). Faculty of Economics and Business, University of Indonesia.

[6] Revindo, M. D. (2017). Types and Severities of Export Barriers: Evidence from Indonesian SMEs. Economics and Finance in Indonesia, 63(2), 150-175.

[7] Hitt, M. A., Hoskisson, R. E., \& Kim, H. (1997). International diversification: Effects on innovation and firm performance in product-diversified firms. The Academy of Management Journal, 40(4), 767-798.

[8] Lu, J. W., \& Beamish, P. W. (2004). International diversification and firm performance: The S-curve hypothesis. The Academy of Management Journal, 47(4), 598-609.

[9] Kim, W. C., Hwang, P., \& Burgers, W. P. (1993). Multinationals diversification and the risk-return trade-off. Strategic Management Journal, 14(4), 275-286.

[10] Caves, R. E. (1996). Multinational enterprise and economic analysis: Cambridge University Press.

[11] Kogut, B. (1985). Designing global strategies: Comparative and competitive value-added chains. Sloan Management Review, 26(4), $15-28$

[12] Olmos, F. M., \& Díez-Vial, I. (2015). Internationalization pathways and the performance of SMEs. European Journal of Marketing, 49(3/4), 420-443. doi:10.1108/EJM-06-2012-0365

[13] Ganotakis, P., \& Love, J. H. (2012). Export propensity, export intensity and firm performance: The role of the entrepreneurial founding team. Journal of International Business Studies, 43(8), 693-718. doi:10.1007/s10997-010-9166-x.

[14] Lu, J. W., \& Beamish, P. W. (2006). SME internationalization and performance: Growth vs. profitability. Journal of International Entrepreneurship, 4(1), 27-48.

[15] Nachum, L. (2004). Geographic and industrial diversification of developing country firms. Journal of Management Studies, 41(2), 273-294. doi:10.1111/j.1467-6486.2004.00432.x

[16] Ruigrok, W., \& Wagner, H. (2003). Internationalization and performance: An organizational learning perspective. Management International Review, 43(1), 63-83.

[17] Singla, C., \& George, R. (2013). Internationalization and performance: A contextual analysis of Indian firms. Journal of
Business Research 66(12) doi:http://dx.doi.org/10.1016/j.jbusres.2013.05.041

[18] Tallman, S., \& Li, J. (1996). Effects of international diversity and product diversity on the performance of multinational firms. Academy of Management journal, 39(1), 179-196.

[19] Lu, J. W., \& Beamish, P. W. (2001). The internationalization and performance of SMEs. Strategic Management Journal, 22(6-7), 565586. doi:10.1002/smj. 184

[20] Siddharthan, N. S., \& Lall, S. (1982). The Recent growth of the largest US Multinationals. Oxford Bulletin of Economics and Statistics, 44(1), 1-13. doi:10.1111/j.1468-0084.1982.mp44001001.x

[21] Kuncoro, M. (2009). Pemberdayaan UKM: Antara Mitos dan Realitas Retrieved 02/10/2014, from http://ekonomikerakyatan.ugm.ac.id/My\%20Web/mudrajad.htm.

[22] Wiratno, U., \& Dhewanto, W. (Undated). Analisis Usaha Mikro, Kecil dan Menengah (UMKM): UMKM Sebagai Pasar Potensial Perbankan. Retrieved from http://xa.yimg.com/kq/groups/20509929/1749183264/name/ANALI SIS+USAHA+MIKRO+KECIL+DAN+MENENGAH++(MBA+IT $\mathrm{B}+$ Business+Review).doc

[23] Ministry of Cooperatives and SMEs Republic of Indonesia, \&. (2011). SME and Cooperative Indonesia Catalogue Jakarta.

[24] Ministry of Cooperatives and SMEs Republic of Indonesia, \&. (2012). SME and Cooperative Indonesia Catalogue Jakarta.

[25] Ministry of Cooperatives and SMEs Republic of Indonesia, \&. (2009a). Direktori KUKM Ekspor Jakarta.

[26] Papke, L. E., \& Wooldridge, J. (1993) Econometric methods for fractional response variables with an application to $401(\mathrm{k})$ plan participation rates. NBER Technical Working Paper No. 147. Cambridge, Mass., USA: National Bureau of Economic Research

[27] Padmadinata, F. Z. S. (2007). Quality management system and product certification process and practices for SME in Indonesia. Paper presented at the meeting of the National Workshop on Subnational Innovation Systems and Technology Capacity Building Policies to Enhance Competitiveness of SMEs, UN-ESCAP and Indonesian Institute of Sciences (LIPI), Jakarta.

[29] Baum, C. F. (2008). Stata tip 63: Modeling proportions. Stata Journal, 8(2), 299-303.

[28] Seifert, B., \& Ford, J. (1989). Are exporting firms modifying their product, pricing and promotion policies? International Marketing Review, 6(6), 53-68.

[30] Wagner, J. (2001). A note on the firm size-export relationship. Small Business Economics, 17(4), 229-237.

[31] Filatotchev, I., Stephan, J., \& Jindra, B. (2008). Ownership structure, strategic controls and export intensity of foreign-invested firms in transition economies. Journal of International Business Studies, 39(7), 1133-1148.

[32] Freeman, S., Edwards, R., \& Schroder, B. (2006). How smaller bornglobal firms use networks and alliances to overcome constraints to rapid internationalization. Journal of International Marketing, 14(3), 33-63. doi:10.2307/25049054

[33] Uchikawa, S., \& Keola, S. (2008). Small and medium enterprises in Cambodia, Laos, and Vietnam. ERIA Research Project Report 2008(5), 237-273. 